\title{
Manipuri (Meetei Mayek) writing system
}

\author{
Lisham Tomba Singh, Ph.D. Scholar, P.Madhubala,Ph.D.
}

\begin{abstract}
This paper makes an attempt to describe the spelling of the Manipuri (Meetei mayek). The present writing system is not a standardized spelling one due to lack of scientific study of this language. Even though Manipuri spelling corresponds with its pronunciation it has a problem to face the spelling of loanwords which do not find in indigenous Manipuri words. In Manipuri writing system thirty five letters are used. Among them, twenty seven letters (alphabet) are known as Ipi Mayek and the remaining eight letters are lonsum mayeks (unreleased letter). In Manipuri writing, lonsum mayek (unreleased letter) represents as unreleased sound at the end of a word or morpheme. If the letter that has no its lonsum mayek is found at the end of a word or morpheme, Ipi mayek is used for it. There is a new finding in spelling in loanwords which do not find in indigenous writing system.
\end{abstract}

\section{Introduction}

Manipuri language is a Tibeto-Burman language of Sino-Tibetan family. It is a schedule language of India. It is understand and spoken by both the valley and hill people. It is also used as a communicative language (lingua franca) among the different tribes of Manipur. It is the only Tibeto-Burman language of India which has its own script to represent the language. The present Manipuri spelling is not standardised form. Many loan words have been imported in this language via Hindi, Bengali, Assamese, Sanskrit and Burmese from different source languages in course of time. Some specific characters are found in Manipuri loan words which are not found in Indigenous Manipuri words. Besides this, the language has free variation of two consonants [ 1 ] and [ $\mathrm{n}$ ]. They can occurred only at the final position of a morpheme or word.

\section{Spelling in Manipuri writing system}

Spelling is an element of orthography and prescriptive element of a language. It is the writing of a word or words with all necessary letters and diacritics present in an accepted standard order. In Manipuri writing system, there are twenty four consonant phonemes, six vowels, six Diphthongs, eight cheitap iyeks. Besides this Manipuri writing also uses eight lonsum, including seven consonant lonsum and one vowel lonsum and three khudam iyeks. The twenty four consonant phonemes are $1 / \mathrm{p} /, \mathrm{h} / \mathrm{t} /, \mathrm{a} / \mathrm{k} /, \mathrm{i} / \mathrm{p}^{\mathrm{h}} / \mathrm{w} / \mathrm{t}^{\mathrm{h}} / \mathrm{g} / \mathrm{k}^{\mathrm{h}} /, \mathrm{c} / \mathrm{b} /, \mathrm{b} / \mathrm{d} /, \mathrm{y} / \mathrm{g}$

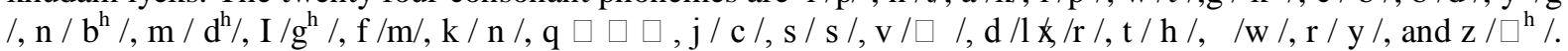

Out of the twenty-four consonants seven consonants have their own lonsum mayeks and the remaining seventeen consonants do not have their own lonsum mayeks. The seven consonant lonsum mayeks are A/ $\square /, \mathrm{F} /$ $\mathrm{m} / \mathrm{L} / \square$ /,D/l/, K /n /, H /t/ , and S / $\square$ /.In Manipuri writing system these seven consonant lonsum mayeks can represent the unreleased sound at the final position of a word. The seven consonant lonsums are given below with examples.

\begin{tabular}{|c|c|c|c|}
\hline $\begin{array}{l}\text { Meetei script } \\
\text { lEA }\end{array}$ & $\begin{array}{c}\text { Phonemic transcription gloss } \\
\square \square \square \square \square \square\end{array}$ & & 'gray hair' \\
\hline oSgED & $\square \square \square \boxminus \square \square \square \square$ & 'garden' & \\
\hline fiF & $\square \square \square \boxminus \square \square \square \square$ & 'place' & \\
\hline $\mathrm{PL}$ & $\square \square \square \square \square \square$ & & 'curse' \\
\hline hPK & $\square \square \square \square \square \square$ & & 'music' \\
\hline $1 \mathrm{PH}$ & $\square \square \square \square \square \square$ & & 'lake' \\
\hline wES & $\square \square \square \square \square \square$ & & 'bridge' \\
\hline
\end{tabular}

In Manipuri writing, lonsum mayek (unreleased letter) represents the unreleased sound of a word or morpheme. If the letter that has no lonsum mayek which occurs at the end of a word or syllable, where Ipi mayek is used for it. These words are mainly of loan words only. The Ipi mayek which can occur at the end of a word or syllable are b,d,s, g,r, $\mathrm{t}^{\mathrm{h}}$ and j, etc.
Meetei script
Phonemic transcription gloss
stx

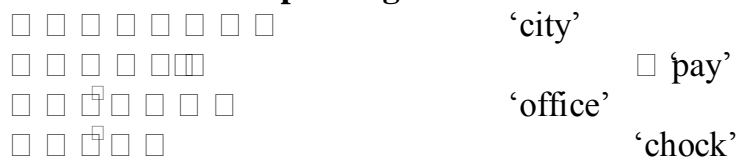
hEdEc
uEiYs
uEw 
$\mathrm{xs} \mathrm{Yb}$

hxcUv

$\square \square \square \square \square \square \square$

$\square \square \square \square \square \square \square \square \square \square$

'receipt'

In Manipuri there are six vowel phonemes. They are $\mathrm{u} / \square / \mathrm{uP} / \mathrm{a} /, \mathrm{o} / \square / \mathrm{uE} / \mathrm{o} / \mathrm{,} \mathrm{uQe} \mathrm{/} \mathrm{and} \mathrm{p} \mathrm{/} \mathrm{u} \mathrm{/.} \mathrm{Among}$ the six vowels, three vowels $(\mathrm{u}, \mathrm{o}, \mathrm{p}) / \square, \mathrm{i}, \mathrm{u} /$ are Ipi mayek and remaining three are formed by adding matra to the Ipi mayek as (uQ,uP,uE)/ $\square$,a,o/.i.e uf $\square \square \square \square \square \square$ 'one',ofP $\square \square \square \square$ 'mother',pK $\square \square \square \square \square$ 'ice',uPO $\square \square \square \square \square$ 'income',udPOjY $\square \square \square \square \square \square \square \square \square$ ' cardamon', There is only one vowel lonsum in Manipuri spelling. It is vowel lonsum $\mathrm{O} / \mathrm{i}$ /. Example dPO / lai / 'picture'. In Manipuri spelling there are six diphthongs .Out of six diphthongs two are made by Ipi mayek with matra i.e $\mathrm{uW} / \square \square / \mathrm{uR} / \square \mathrm{u} /$ and othefour diphthongs are formed by one Ipi mayek and one vowel with matra i.e uPp / $\square \square \square /$, uPO / ai /,uEO /oi / and pO / ui /. examples are 1Pp $\square \square \square \square$ 'news', fPO / $\square \square \square$ / 'face',gEO / $\square \square \square \square \square /$ 'bee', tUO / $\square \square \square \square /$ 'dog', dW / $\square \square$ 'flower 'and fR / $\square \square \square \square /$ 'woman'.

In Manipuri spelling there are eight cheitap mayeks. They are o /e /, E / $\square \square /, \quad \mathrm{U} / \mathrm{u} /, \mathrm{R} / \square \mathrm{u} / \mathrm{W} / \square \square / \quad \mathrm{P} / \square /$ $\mathrm{Y} / \square /$ and $\mathrm{T} / \square /$.Out of eight cheitap mayek seven are vowel matras and one is consonant matra. The eight cheitap mayeks are attached to consonant and vowel letter. They are as follows.

$\begin{array}{ccll}\text { Meetei script } & \text { Phonemic transcription } & \text { gloss } & \\ \text { o /e / jQ } & / \square \square / \text { 'paper' } & \\ \mathrm{E} \square \square \square / \mathrm{fEK} & / \square \square \square / & \text { 'pillow' } \\ \mathrm{U} / \mathrm{u} / \mathrm{aUK} & / \square \square \square / & \text { 'twenty' } \\ \mathrm{R} / \square \mathrm{u} / \mathrm{fR} & / \square \square \square / & \text { 'women' } \\ \mathrm{W} / \square \square / \mathrm{fW} & / \square \square \square / & \text { 'fire' } \\ \mathrm{P} / \square / \text { fPO } & / \square \square \square / & \text { 'face' } \\ \mathrm{Y} / \square / \mathrm{fY} & / \square \square / & \text { 'human' } \\ \mathrm{T} / \square / \mathrm{kUT} & / \square \square \square / & \text { 'stone' }\end{array}$

In Manipuri spelling the use of cheitap mayek is very common. There are two forms of writing cheitap mayek as (a) the attachment of one cheitap mayek to a letter of a word and (b) the attachment of two cheitap mayeks to a letter of a word. For example attachment of one cheitap mayek i.e. $f+W=f W / m \square i /$ 'fire', $f+T=$ $\mathrm{fT} / \mathrm{m} \square \square /$ 'dream', andalso the attachment of two cheitap mayeks to a letter i.e. a+ $\mathrm{P}+\mathrm{T}=\mathrm{aPT} / \mathrm{k} \square \square /$ 'mosquito', g+ P+T=gPT / $\mathrm{k}^{\mathrm{h}} \square \square /$ 'pan',The writing order between atap ( $\mathrm{P}$ ) and nung (T), atap is attached to the letter first and nung follows it i.e. PT/a $\square /$, ET/o $\square /$, UT/u $\square /$ and YT/i $\square /$.(Wakoklol hillel thilel amailol pukok puya).

Additional examples of attachment of one cheitap mayek:

\begin{tabular}{|c|c|c|}
\hline Meetei script & Phonemic transcription & gloss \\
\hline /e / $1 Q$ & $/ \square \square /$ & 'a type of umbrella' \\
\hline $\mathrm{E} \quad / \square \square \Lambda \mathrm{EK}$ & $/ \square \square \square$ & 'cage' \\
\hline $\mathrm{U} / \mathrm{u} / \mathrm{hU}$ & $/ \square \square /$ & 'body hair' \\
\hline $\mathrm{R} \quad / \square \mathrm{u} / \mathrm{kR}$ & / $\square \square \square /$ & 'oar' \\
\hline $\mathrm{W} \quad / \square \square \jmath \mathrm{jW}$ & $/ \square \square \square / /$ & 'stick' \\
\hline $\mathrm{P} \quad / \square / \mathrm{sP}$ & $/ \square \square /$ & 'animal' \\
\hline $\mathrm{Y} \quad / \square / \mathrm{tY}$ & $/ \square \square /$ & 'boat' \\
\hline $\mathrm{T} \quad / \square / \mathrm{lUT}$ & $/ \square \square \square$ / & 'hour' \\
\hline
\end{tabular}

Additional examples of attachment of two cheitap mayeks to a letter.

\begin{tabular}{|c|c|}
\hline Phonemic transcription & gloss \\
\hline oT /e $\square$ /dQTc / $\square \square \square \square \square /$ & 'to move' \\
\hline ET $\quad / \square \square \square$ VETc & 'boast' \\
\hline $\mathrm{TU} / \mathrm{u} \square / \mathrm{hTU} / \square \square \square /$ & 'back' \\
\hline$/ \mathrm{a} \square / \mathrm{dPT} / \mathrm{a} \square /$ & 'net' \\
\hline YT $/ \square \square$ fYT / $\square \square \square /$ & 'name' \\
\hline
\end{tabular}

III. Use of Khudam Mayek:

In Manipuri spelling three khudam mayeks are used. They are 'lum' (.) as tone mark, 'apun ( ) cluster mark and 'cheikhei' (.) full stop mark. Lum (.) is used as a marker of tone. 


\section{Lum $\overline{(.)}$ tone mark:}

In Manipuri there are two types of tone. They are low and high tone. In Manipuri language high tone is marked while low tone is unmarked. In Manipuri language context also decides the meaning significantly. In Manipuri spelling, tone mark is not used in the sentence level. But in the paradigm form of words in word level tone mark is required .i.e. for high tone; a tone mark (.) lum is used. Examples are given below:

'I' o. / $\square \mathrm{i} / \quad$ 'blood' high tone

'I' o/ i / 'thatch', low tone

'Mi' fY. / $\square \mathrm{i} / \quad$ 'human' high tone

'Mi' fY /i/ 'spider' low tone

Apun $\square \square \square$ Vòluster mark:

Apun $\square \square \square$ V)is also a khudam mayek whichis used in Manipuri spelling as cluster mark of consonant phonemes for initial cluster, medial cluster and final cluster.i.e $\mathrm{k}^{\mathrm{h}}+\mathrm{w}>\mathrm{k}^{\mathrm{h}} \mathrm{w}: \mathrm{g}+\mathrm{e}>\mathrm{ge}$ : gePS $/ \mathrm{k}^{\mathrm{h}} \mathrm{wa} \square /$ 'waist', $\mathrm{a}+\mathrm{x}>\mathrm{ax}$ : dWaxA/leikr $\square \mathrm{k} /$ 'crack', $\mathrm{n}+\mathrm{c}>\mathrm{ns}$ : $\mathrm{k}+\mathrm{j}>\mathrm{kj}$ : cxPks /brans / 'branch'.

\section{Cheikhei (.) full stop mark:}

Cheikhei (.) is full stop mark. It is used at the end of a sentence. Example uW jPA jPxQ. / $\square \mathrm{i}$ cak care/ 'I have eaten_meal' In The early Manipuri spelling, the use of (T) nung cheitap mayek is used in case of attachment of one cheitap mayek and two cheitap mayeks to a letter.(Wakoklon Hillel Thilel Amailon Pukok Puya p.2) But in modern Manipuri writing system (S) ngou lonsum is more popularly used than of (T) nung cheitap mayek The use of(S) ngou lonsum can make easier to write and read to the user and learner.

The following chart shows the different writing system between (T) nung and (S) ngou lonsum.

\begin{tabular}{|c|c|c|c|}
\hline (T) nung & (S) ngou lonsum & Phonemic transcription & gloss \\
\hline aPT & aPS & $/ \mathrm{ka} \square /$ & 'mosquito' \\
\hline jQT & jQS & $/ \mathrm{ce} \square /$ & 'rice' \\
\hline gET & gES & $/ \mathrm{k}^{\mathrm{h}} \mathrm{O} \square /$ & 'leg' \\
\hline kUT & $\mathrm{kUS}$ & $/ \mathrm{nu} \square /$ & 'stone' \\
\hline jYT & jYS & $/ \mathrm{ci} \square /$ & 'hill' \\
\hline
\end{tabular}

Fig-1

The above examples show that the writing system of (S) ngou lonsum is easier to read and write than (T) nung cheitap mayek. There is a corresponding relationship between writing and its pronunciation in Manipuri language, for example jPc /cab $\square$ /'to eat', wAl /th $\square \mathrm{kp} \square /$ 'tdrink' jHl /c $\square$ tp $\square$ / 'togo'. In Manipuri, the writing of the letter/b/ is used but pronounced as [p] as in the words like $\mathrm{nPc} /$ bhap / 'idea', $\mathrm{kEcPc} /$ nobap / 'citrus maxima'. Another example is that, $/ \mathrm{g} /$ is used in writing but pronounced as $/ \mathrm{k} /$ in some words like 'dag' $\mathrm{bPy} / \mathrm{dak} /$ 'mark'. In English language there is no correspondence between sound and spelling system, for example in the word doubt /dowt/ the sound /b/ is silent but it is used in English writing system.

\section{Spelling in Manipuri loan words}

It is generally agreed that the entry of loan words in a language from other languages correlates with acculturation and cultural diffusion (Lehmann 1962:216). There are a lot of loanwords in Manipuri language. In course of time they are also a part of Manipuri language. Loanword may be defined "as a word copied into one language from another language" (R.L.TraskKey concepts in Language and Linguistics, 2005 p-175). Most of the loan words in Manipuri begin with the phonemes I $\square \square \square \square \square \square \mathrm{j} \square \square \square \square \square \square \square \square \square \square \square \square \square \square \square$ Manipuri loan words are entered in different ways i.e. these loan words are entered in the words of electronic items, food items, transport and communication items, religious items, sports items and educational items etc.

Manipuri loan words are imported from different language sources. The source language of Manipuri loan words are 1.Indic(Sanskrit, Hindi, Bengali, and Assamese) 2.Iranian(Persian and Pashto) 3.Other IndoEuropean(English, Portuguese, French and Greek) 4.Non-European (Arabic, Turkish, Tamil, Malay, Chinese ,Burmese and Japanese).In Manipuri language the source language are imported as loan words directly or indirectly via Hindi, Bengali, Assamese and Sanskrit. In the following some loan words are given which are used in Manipuri as directly. 


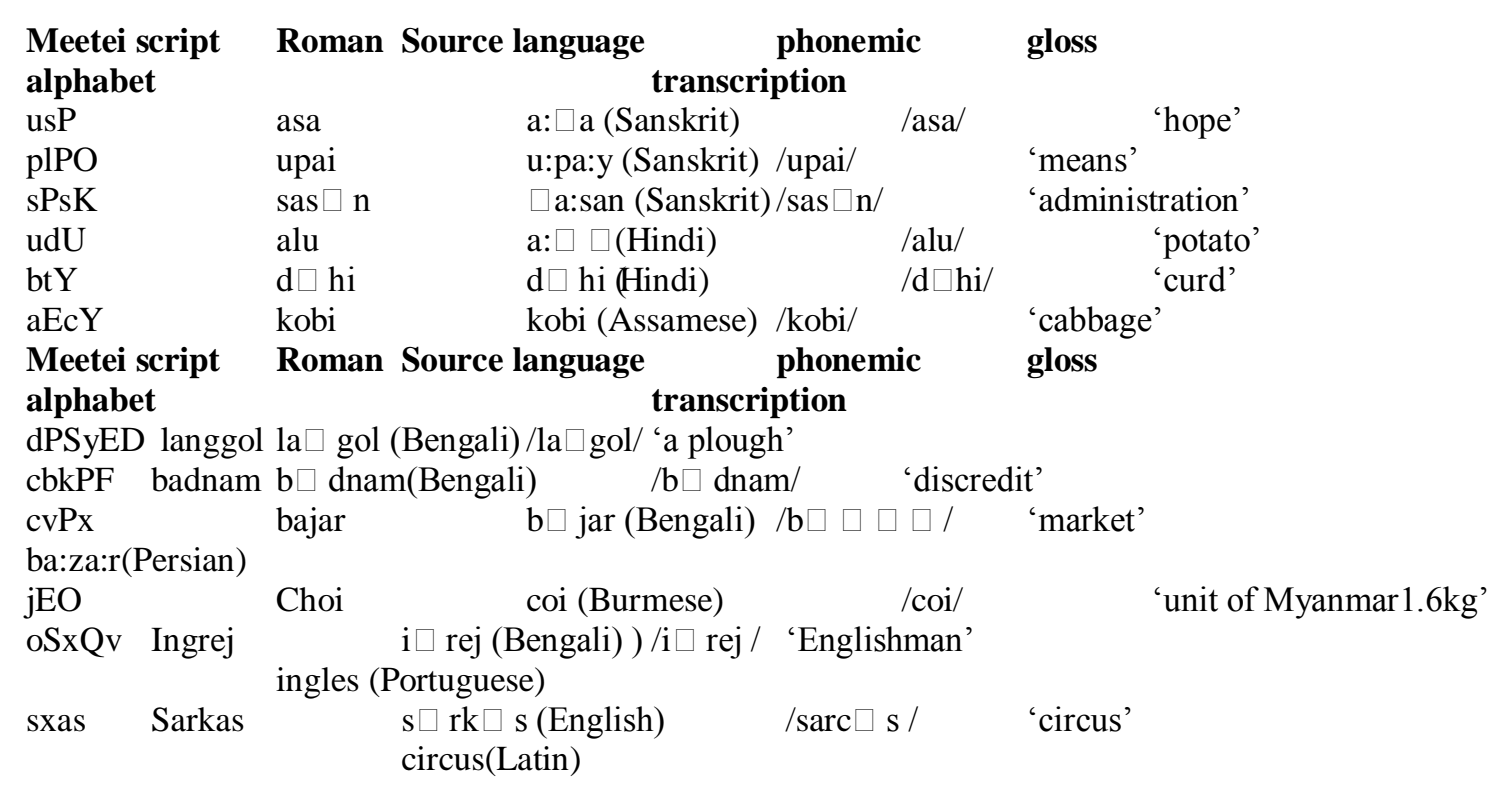

In Manipuri language some loan words are used indirectly from the source language. Some examples are given below. Roman

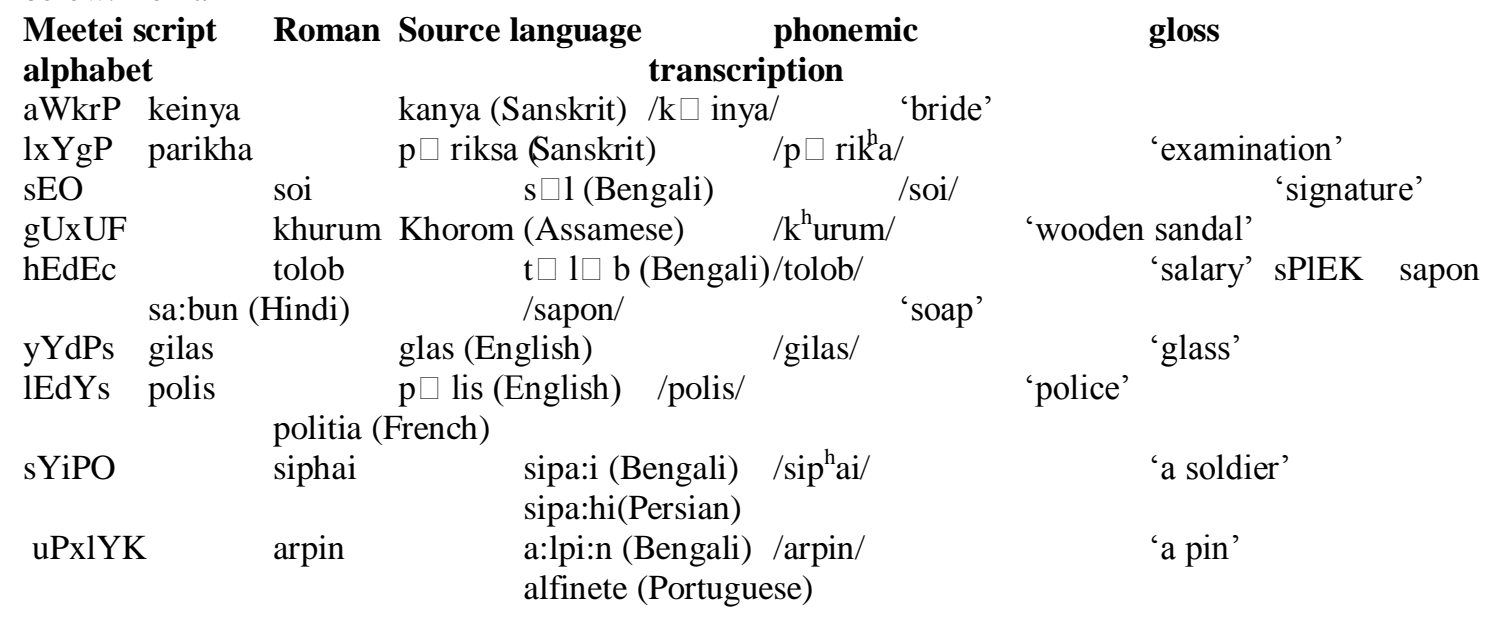

IV. Spelling of Manipuri Consonant cluster

It is a combination of two consonants within a syllable or in other word, utterance of two sounds at a time. Like many other Tibeto-Burman languages, Manipuri has three consonant cluster i.e. initial, medial and final clusters. There is no final cluster in indigenous Manipuri words. Final clusters are found in loan words only. In Manipuri Script, the cluster is marked by an underlined which is called 'apun' in Meetei script. The examples of Manipuri consonant cluster are as follows.

\section{Initial cluster}

In the initial cluster, the cluster of consonant are occurred at the initial position of a word. The consonant phoneme $\mathrm{k}+\mathrm{w}>\mathrm{kw}, \mathrm{k}^{\mathrm{h}}+\mathrm{w}>\mathrm{k}^{\mathrm{h}} \mathrm{w}, \mathrm{s}+\mathrm{w}$ i.e.

Meetei script phonemic transcription gloss

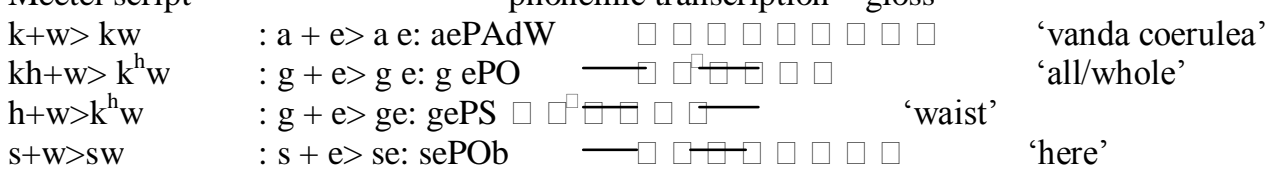

\section{Medial cluster}

In the medial cluster, the cluster of consonant are occurred at the medial position of a word. The consonant phoneme $\mathrm{p}+\mathrm{r}>\mathrm{pr}, \mathrm{k}+\mathrm{r}>\mathrm{kr}, \mathrm{kh}+\mathrm{r}>\mathrm{khr}, \mathrm{b}+\mathrm{r}>\mathrm{br}$ i.e.

Meetei script phonemic transcription gloss 


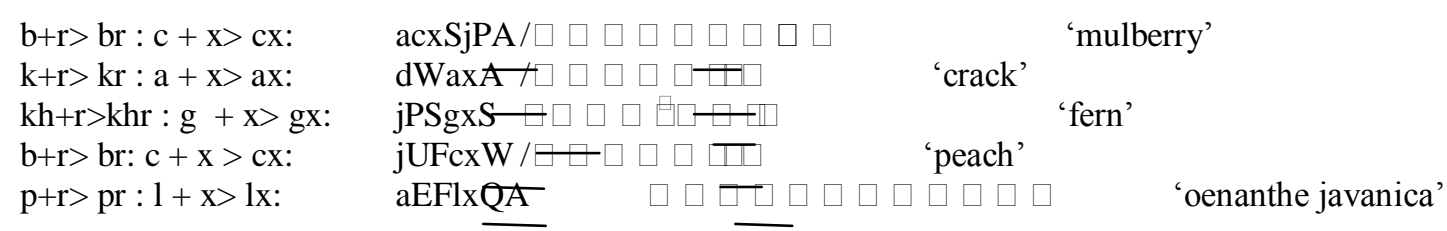

\section{Final cluster}

The final clusters are found in Manipuri loanwords. But the occurrence of final cluster is rare in comparison to initial and medial cluster. Examples are given below:

Meetei script

$\mathrm{k}+\mathrm{s}>\mathrm{ks}: \mathrm{a}+\mathrm{s}>$ as: yxiYAs phonemic transcription gloss $/ \square \square \square \boxminus \square \square \square /$ graphics $\square \square \quad$ 'designs'

$\mathrm{n}+\mathrm{c}>\mathrm{ns}: \mathrm{k}+\mathrm{j}>\mathrm{kj}$ : cxPKs $-\quad T \square \square \square \square /$ branch $\square \square \square \square \square \square \square$ apart of something'

the word 'branch 'the consomrant ctuster is occurred at the final as cxPKs/brans/.Here, the sound / c / is replaced by the nearest equivalent sound / s /. In Manipuri in the final cluster, the first letter out of two clusters consonant is written by lonsum mayek if the sound has lonsum mayek.

There are some loan words which have no final cluster in pronunciation but writing in Meetei script it is written as final cluster form. They are as follows with examples.
Meetei script
$\mathrm{t}+\mathrm{r}>\operatorname{tr} \quad: \mathrm{h}+\mathrm{x}>\mathrm{hx}: \mathrm{fKhx}$ phonemic transcription gloss
$\mathrm{t}+\mathrm{r}>\operatorname{tr} \quad: \mathrm{h}+\mathrm{x}>\mathrm{hx}: \mathrm{vKhx}$
$/ \square \square \square \square \square \square /$ mantra $\square \square \quad$ 'incantations'
$\mathrm{t}+\mathrm{r}>\operatorname{tr} \quad: \mathrm{h}+\mathrm{x}>\mathrm{hx}: \mathrm{sPhx} / \square$

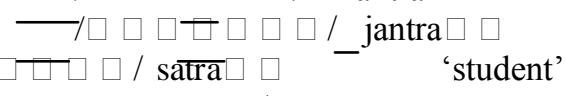
$\mathrm{t}+\mathrm{r}>\mathrm{tr} \quad: \mathrm{h}+\mathrm{x}>\mathrm{hx}: \mathrm{yEhx} \quad-/ \square \square \square \square \square /$ gotra
t+r $>$ tr $\quad:$ h + x>hx: lhx $\quad / \square \square \square \square \square /$ patra $\square$
'clan or caste'
'paper'
'music'

\section{Free variation in Manipuri spelling}

Free variation in linguistics is the phenomenon of two (or more) sounds or forms appearing in the same environment without a change in meaning and without being considered incorrect by native speakers. 'Free variation in phonology, referring to the substitutability of one sound for another in a given environment with no consequent change in the words meaning, as when a speaker articulates a word like sit with an unreleased or a released plosive or different pronunciation"- (David Crystal, July $20086^{\text {th }}$ Edition). Manipuri spelling has its free variation. When two consonant phonemes that / $1 /$ and /n /in the initial position they establish as different phonemes but when these two phonemes occur at final position they become free variation in Manipuri language. Some examples are given below:-

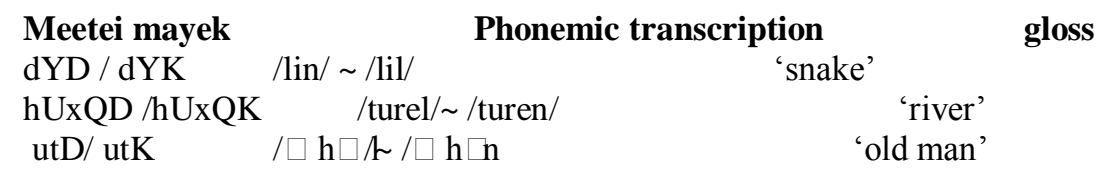

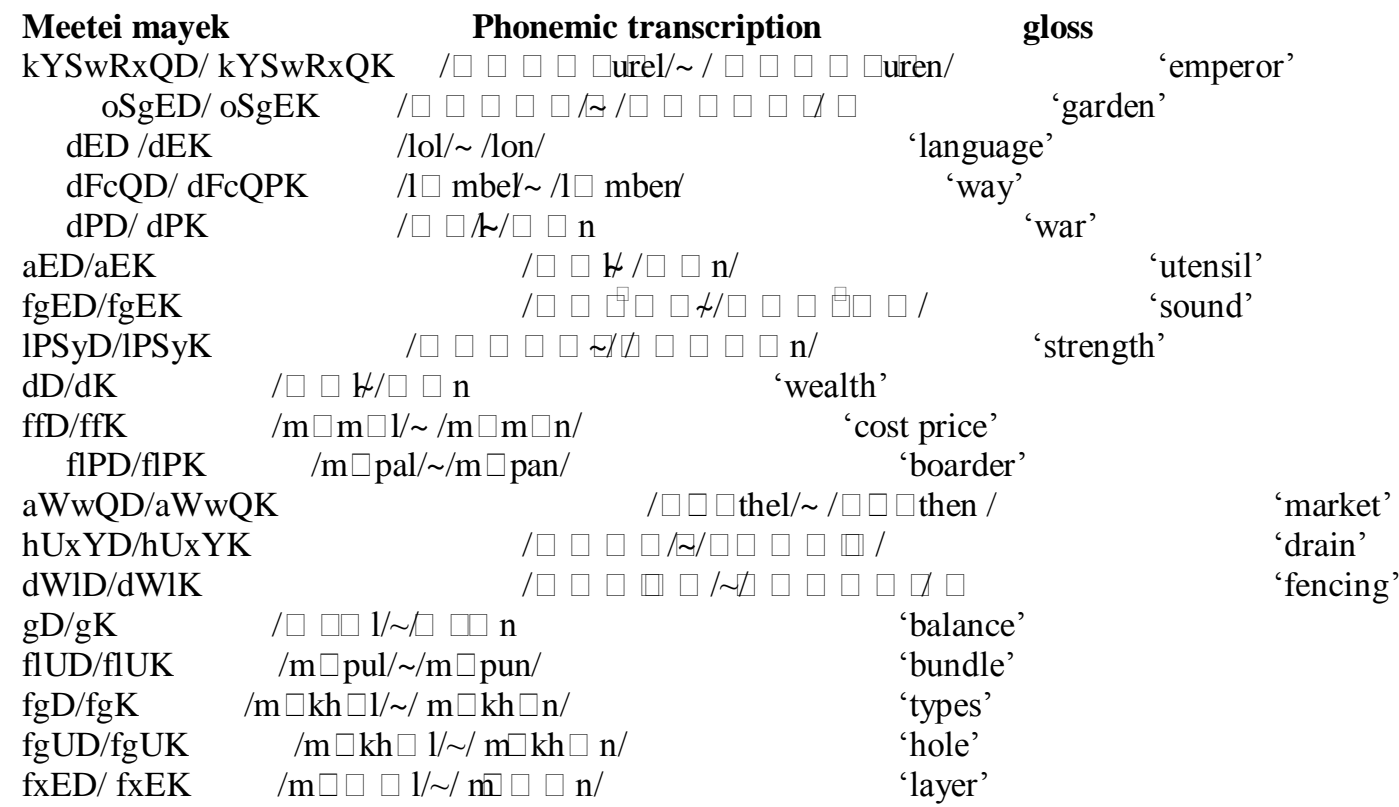




\section{Conclusion}

This study will be a permanent record of Manipuri language. It will be useful to the new researchers and new learners. No one had work in this field in the past. From the above discussion on the spelling of Manipuri (Meetei mayek), there is a corresponding relationship between writing and its pronunciation. Manipuri language has eight lonsum mayeks (unreleased letters) to represent eight letters, when they occurred at the final position of a morpheme or a word. In present Manipuri (Meetei Mayek) writing system, the used of retroflex letter is not found. In Manipuri, apun (cluster mark) indicates the cluster letters of the morpheme or word. In Manipuri loan words, if the phonemes $[\mathrm{b}],[\mathrm{d}],[\mathrm{g}]$ and $[\mathrm{r}]$ are occurred at the final position of a morpheme or word, they are represented by Ipi mayeks not lonsum due to lack of unreleased letter of the representation of lonsum. In some specific way of writing of loan words, there is replacement of sound by its nearest equivalent Ipi mayek sound. No addition of atap [a] is used in present Manipuri writing system.

\section{Reference}

[1]. Grierson G.A.1903 Linguistics survey of India Vol.III, Part III Motilal Banarsidar, Delhi

[2]. Madhubala P. 2002 Manipuri Phonology, Imphal

[3]. Yaswanta Singh Ch.2000 Manipuri Grammar, New Delhi

[4]. M S Ningomba.1992 Meitei Lonmit, Imphal

[5]. P.C. Thoudam. 1991 Remedial Manipuri, Imphal

[6]. Hocket C.F. 1958 A course in Modern linguistics New York

[7]. Danial Jones. 1979 An outline of English Phonetics New Delhi

[8]. Kangjia Mangang Ng.2003History of Kanglei Iyek, Imphal

[9]. Khelchandra Singh N.1967 Ariba Manipuri Itihas, Imphal

[10]. Sanatomba Singh. 1994 Origin and Development of Meitei Script, unpublished Ph.D.thesis Manipur University

[11]. Ibungohal and Khelchandra N 1967 Cheitharol Kumbaba, Imphal

[12]. Varshney R.L.2005 An Introductory Text book of Linguistics and phonetics Bareilly

[13]. T.C.Hodson 1908The Meitheis Delhi

[14]. H. Subadani Devi 2004 Loanwords in Manipuri and their impact

[15]. David Crystal A Dictionary of Lingistics and Phonology 